\title{
Food and nutrition in the Indo-Gangetic Plain region - a disaggregate level analysis
}

\author{
Hukum Chandra, Kaustav Aditya*, Swati Gupta, Saurav Guha and \\ Bhanu Verma
}

ICAR-Indian Agricultural Statistics Research Institute, Library Avenue, New Delhi 110 012, India

\begin{abstract}
India is an agriculture-based country which has experienced enormous change in food and nutrition utilization since financial changes in the mid-1990s. Agribusiness is considered as the backbone of Indian economy. Therefore, the Indo-Gangetic Plain (IGP) holds agricultural importance, contributing to a major share of our national income. High financial development rates of Indian economy have neglected to enhance food security in the country. The welfare of an expanding economy is not shared equally as the country is still home to one-third of the world's poor. Hunger in India is considered as a genuine imprint on its development, and food security has now evolved as a principal issue. Presently, agriculture, nutrition, and dietary security are the prime worry for India to accomplish the target of encroachment. A large portion of the Indian population lacks healthy sustenance and nourishment. This article demonstrates nourishment utilization design across selected social and economic groups in the states falling under IGP region of India, which include West Bengal, Bihar, Uttar Pradesh, Punjab and Haryana. The analysis helps in distinguishing the disparities among calorie, protein and fat consumption in the IGP region. An effort is made to recognize socio-economic groups suffering from deficiencies in nutrition consumption.
\end{abstract}

Keywords: Agriculture, calorie intake, food security, nourishment, rural households.

INDIA is one of the most important developing countries in Southeast Asia. At present, India is one of the fastest developing economies in the world. The country has progressed significantly in reforming its economy, reducing the needs and enhancing expectations for the everyday comforts of its vast population. India has the second largest area of arable land in the world and is a major producer of various agricultural products ${ }^{1}$. The Indo-Gangetic Plain (IGP) region consists of around 630 million acre fertile land, including northern areas of the Indian subcontinent and the majority of northern and eastern parts of India. The IGP region is home to nearly one-seventh of the world's population, and covers the Indian states of West Bengal, Bihar, Uttar Pradesh, Punjab and Haryana.

*For correspondence. (e-mail: kaustav.aditya@icar.gov.in)
Due to its agricultural importance, IGP is considered as the food basket of India, and is often termed as the 'Granary of India'. Therefore, the IGP region is agriculturally and economically extremely important to the country. Despite productivity enhancements in the Indian agricultural sector in the recent decades, there exists wide variation in the estimates of undernourished population among different sources. Satisfactory explanations are not available on why the expansion in per-capita income and food production has not been able to reduce undernourishment except for some factors like lack of knowledge about nutrition, deliberate hunger, etc. ${ }^{2}$. As indicated by a World Bank report', 'South Asia still has the most astounding rates and the biggest number of undernourished kids on the planet'. Furthermore, 'the high financial development experienced by South Asian nations has not had an effect on the wholesome status of South Asian families, ${ }^{3}$.

In 2019, India was ranked at the 103rd position among 119 countries on the Global Hunger Index. The country has shown major advancement in several areas like innovation, craftsmanship, science, protection, industrialization, etc. However, the fundamental dietary needs of a large portion of the population are yet to be satisfactorily met. Guaranteeing nourishment to the public through providing access to nutritious food and therefore providing food security stayed one of the most important objectives of the nation since independence. This is being accomplished by hastening development in food and nourishment, enhancing monetary access to food supplies, giving financed food grain, etc. Although several steps have been taken, numerous studies have demonstrated that no noteworthy advancement could be accomplished in diminishing hunger and under-nourishment in the country. There are several assessments of the undernourished population among various sources and a few of them have even revealed worsening in the condition over time $^{4-7}$.

Food accessibility has significantly expanded in India over the previous decades because of the Green Revolution. Accomplishing food security is the essential focus in India. According to the Food and Agriculture Organization (FAO), Rome, food security exists when all individuals, consistently, have physical and financial access to adequate, safe and nutritious nourishment to meet their dietary needs 
and nourishment inclinations for a functioning and solid life. Food security has three segments: availability, accessibility, and utilization and vulnerability. All these are interconnected. Numerous studies have demonstrated that enhancement in nutrition is important for expanding efficiency among the population of a country. India's fundamental activities to guarantee food security range from deliberate efforts to support agricultural production to the far-extending market aiming for both salary and value adjustment. Globally, food security is defined as follows: '...all people, at all times, have physical and economic access to sufficient, safe and nutritious food to meet their dietary needs and food preferences for a healthy and active life ${ }^{, 8}$. With the aim of being food-secure, it is essential for the people of a country to consume a stable diet comprising calories and adequate nutritious food. In India, consumption of calorie, protein and fat is the basis for characterizing poverty and food insecurity. The nutrition intake across the Indian states under the IGP region can help stimulate discussion about the drivers of hunger in them. The significance of this study is that it provides an outlook about food security parameters at the IGP region through the observed outcomes for food and its associative supplements.

\section{Material and methods}

Data from the National Sample Survey Office (NSSO), Ministry of Statistics and Programme Implementation (MoSPI), Government of India (GoI) are the primary source of official statistics at the national and state levels. In this analysis we have used Household Consumer Expenditure Survey data collected by NSSO in its 68th round during 2011-12 (HCES 2011-12). The HCES 2011-12 is recent available data till date. This Survey includes a total of 7469 villages, 59,695 rural sample households in Schedule Type 1 and 59,683 rural households in Schedule Type 2. Altogether 5915 rural households were surveyed from Uttar Pradesh, 3310 from Bihar, 3566 from West Bengal, 1552 from Punjab and 1423 from Haryana. The Survey provides information on quantity and value of more than 142 food items with a reference period of last 30 days for a few food items and the last 7 days for rest of the food items for each State and Union Territory separately for rural and urban areas. In this study, Schedule Type 2 was used to gather information on consumption of rural households across states under the IGP region for processing of results.

The following socio-economic and regional variables were selected and recoded from the HCES 2011-12 unitlevel data for this analysis in the IGP states.

- Occupation type (household type): This study is based on rural households and therefore, rural occupation categories have been used. Six types of rural occupa- tion were selected, viz. self-employed in agriculture (SEA), self-employed in non-agriculture (SENA), regular wage/salary (RWS), casual labour in agriculture (CLA), casual labour in non-agriculture (CLNA) and others.

- Land category: It categorizes rural households on the basis of land-holding size (ha). There are three categories: marginal (households having land size less than $1 \mathrm{ha}$ ), small (households having land size $\geq 1$ and $<2 \mathrm{ha}$ ), and Others (households having land size $\geq 2$ ha).

- Social group (caste): This includes scheduled tribe (ST), scheduled caste (SC), other backward class (OBC), and Others.

To estimate nutrient intake, the suggested intake of food items was transformed into calorie, fat and protein ${ }^{9}$. One of the constraints of the NSSO statistics is that it is a record on meals intake at the household level. Therefore we cannot include the intra-household disparities of food consumption. In the present analysis all the estimates were averaged as per capita on family degree. According to the Ministry of Health and Family Welfare, GoI ${ }^{9}$, average dietary energy intake per person per day in rural India is $2400 \mathrm{kcal}$.

The major aim of this study was to compute the average calorie, protein and fat intake among rural households of the IGP region. Let us first describe some notations used in the estimation of various parameters. Let us assume a finite population $U$ of size $N$, and let a samples $s$ of size $n$ be selected from this population. We assume that the target variable of interest $y$ is binary; for example, whether a household is food-insecure (household consuming less than $2400 \mathrm{kcal}$ per day), or otherwise. The $i$ th unit related to the target variable $y$ is defined as $y_{i}=1$, if $i$ th household is food-insecure and $y_{i}=0$, otherwise, with $i=1, \ldots, n$. With this background, we estimate the population proportion $P=N^{-1} \sum_{i \in U} y_{i}$, i.e. the proportion of rural families that are not getting satisfactory amount calories consistently (also referred to as food-insecure households). The estimator for the proportion is given by $\hat{p}_{w}=\sum_{i \in s} w_{i} y_{i}$, where $w_{i}=w_{i}^{*} / \sum_{i \in s} w_{i}^{*}$ is the normalized survey weight for the $i$ th unit and $w_{i}^{*}$ is the survey weight for the $i$ th unit in the sample. Following Särndal et al. ${ }^{10}$, variance of the estimator $\hat{p}_{w}$ was approximated by $\operatorname{var}\left(\hat{p}_{w}\right) \approx \sum_{i \in s} w_{i}\left(w_{i}-1\right)\left(y_{i}-\hat{p}_{i}\right)^{2}$. We have utilized this methodology and processed the foodinsecure households along with proportion and coefficient of variation $(\mathrm{CV})$.

\section{Results and discussion}

Economic poverty and lack of purchasing power are considered to be the two main factors for low dietary intake and under-nourishment. Malnutrition in India is the result 
of the usual suspects: widespread poverty, endemic hunger, rapid population growth, pockets of poor administration, mediocre health systems and untrustworthy national indicators, which are all aggravated by issues of rank, ethnicity, religion and sexual orientation. We have taken into account the nutrition profile of the IGP states and its variations among rural households according to their land-holding capacity, occupation and socio-economic groups to determine food consumption patterns. The analysis illustrates that the consumption of different food items varies among socio-economic groups and regions. Moreover, household size is one of the important determinants of food consumption.

Table 1 shows the average calorie, protein and fat intake of rural households from the states of IGP region based on the sample size taken from HCES 2011-12. From the table, it can be observed that the major agrarian states like Punjab and Haryana have average levels of calorie intake $11 \%$ higher than the all-India average, i.e. $2233 \mathrm{kcal}$ per capita for rural households, whereas the remaining three states in the IGP region have average levels of calorie intake at par with the all-India average. Further, the all-India level average protein and fat intake are 60.7 and $46.1 \mathrm{~g}$ per capita respectively, for rural households. It is interesting to note that the inter-state disparity in protein and fat intake is wider than the average level of calorie intake. Protein intake in the IGP states varies from $55.6 \mathrm{~g}$ (West Bengal) to $72.8 \mathrm{~g}$ (Haryana), whereas fat intake varies from $35.2 \mathrm{~g}$ (West Bengal) to $70.3 \mathrm{~g}$ (Punjab).

Table 2 shows the occupation-wise average calorie intake and proportion of food insecurity among rural households in different states of the IGP region. The average level of calorie intake in the IGP states varies from 2199 (West Bengal) to $2483 \mathrm{kcal}$ (Punjab). The occupation-wise variation in average calorie intake among these states is the lowest in Uttar Pradesh (-4\% to $4 \%$ ) and highest in Punjab (-9\% to $13 \%$ ) compared to the overall average calorie intake of the respective states. It is also noted that the households under SEA have the highest average calorie intake among all the IGP states, ranging from 2270 (Uttar Pradesh) to $2810 \mathrm{kcal}$ (Punjab), which in turn makes them nutritionally more secure and healthy whereas households under CLNA have the lowest average calorie intake that varies from 2113 (Uttar

Table 1. Average values of calorie, protein and fat intake per person per day for rural areas in the Indo-Gangetic Plain (IGP) region

\begin{tabular}{lccc}
\hline State & Calorie $(\mathrm{kcal})$ & Protein $(\mathrm{g})$ & Fat $(\mathrm{g})$ \\
\hline Uttar Pradesh & 2200 & 62.6 & 42.6 \\
Bihar & 2242 & 62.9 & 39.2 \\
West Bengal & 2199 & 55.6 & 35.2 \\
Punjab & 2483 & 70.0 & 70.3 \\
Haryana & 2441 & 72.8 & 68.5 \\
India & 2233 & 60.7 & 46.1 \\
\hline
\end{tabular}

Pradesh) to $2246 \mathrm{kcal}$ (Punjab). Further from Table 2, it can be observed that the proportion of food insecurity in the IGP states varies from 0.50 (Punjab) to 0.73 (West Bengal). The variation of food insecurity among the occupational groups within a state is highest in Punjab $(-44 \%$ to $38 \%)$ and lowest in West Bengal $(-11 \%$ to $0.05 \%$ ) compared to the proportion of food insecurity in the respective states.

Table 3 shows the occupation-wise average protein and fat intake in the IGP states along with their percentage CV. Punjab and Haryana have outdone the other states in the region in average protein and fat intake, irrespective

Table 2. Occupation-wise distribution of households (\%), sample size, calorie intake, proportion of food insecurity (PFI) and percentage coefficient of variation (CV) in the IGP states

\begin{tabular}{|c|c|c|c|c|c|c|}
\hline Category & $\begin{array}{c}\text { Distribution } \\
\text { of house- } \\
\text { holds (\%) }\end{array}$ & $\begin{array}{c}\text { Sample } \\
\text { size }\end{array}$ & $\begin{array}{c}\text { Calorie } \\
\text { (kcal) }\end{array}$ & $\% \mathrm{CV}$ & PFI & $\mathrm{CV}$ \\
\hline \multicolumn{7}{|c|}{ West Bengal } \\
\hline All & & 3566 & 2199 & 0.90 & 0.73 & 1.74 \\
\hline SEA & 19.22 & 599 & 2388 & 2.81 & 0.65 & 5.14 \\
\hline SENA & 23.16 & 1282 & 2160 & 1.54 & 0.76 & 2.47 \\
\hline RWS & 7.36 & 530 & 2222 & 1.98 & 0.72 & 4.61 \\
\hline CLA & 33.82 & 557 & 2119 & 1.34 & 0.76 & 3.32 \\
\hline CLNA & 10.43 & 413 & 2116 & 1.88 & 0.77 & 4.16 \\
\hline Others & 6.08 & 185 & 2341 & 2.94 & 0.66 & 8.89 \\
\hline \multicolumn{7}{|l|}{ Bihar } \\
\hline All & & 3310 & 2242 & 0.73 & 0.68 & 2.15 \\
\hline SEA & 33.58 & 945 & 2344 & 1.35 & 0.58 & 5.03 \\
\hline SENA & 18.94 & 1014 & 2202 & 1.21 & 0.70 & 3.40 \\
\hline RWS & 3.95 & 274 & 2341 & 2.04 & 0.61 & 9.31 \\
\hline CLA & 26.27 & 385 & 2169 & 1.76 & 0.77 & 3.88 \\
\hline CLNA & 8.77 & 379 & 2119 & 1.44 & 0.77 & 3.89 \\
\hline Others & 8.49 & 313 & 2199 & 2.05 & 0.74 & 5.38 \\
\hline \multicolumn{7}{|c|}{ Uttar Pradesh } \\
\hline All & & 5915 & 2200 & 0.51 & 0.71 & 1.34 \\
\hline SEA & 45.22 & 2254 & 2270 & 0.81 & 0.67 & 2.44 \\
\hline SENA & 16.14 & 1363 & 2128 & 1.11 & 0.77 & 2.28 \\
\hline RWS & 5.25 & 504 & 2214 & 1.70 & 0.69 & 4.28 \\
\hline CLA & 10.85 & 345 & 2109 & 1.67 & 0.77 & 3.87 \\
\hline CLNA & 17.88 & 1189 & 2113 & 0.90 & 0.78 & 2.26 \\
\hline Others & 4.67 & 260 & 2295 & 3.62 & 0.65 & 7.01 \\
\hline \multicolumn{7}{|l|}{ Punjab } \\
\hline All & & 1552 & 2483 & 0.91 & 0.50 & 3.67 \\
\hline SEA & 25.31 & 447 & 2810 & 1.83 & 0.28 & 11.82 \\
\hline SENA & 15.72 & 298 & 2345 & 1.59 & 0.61 & 6.26 \\
\hline RWS & 16.12 & 265 & 2363 & 1.74 & 0.55 & 7.72 \\
\hline CLA & 15.11 & 137 & 2360 & 2.46 & 0.58 & 10.05 \\
\hline CLNA & 19.49 & 296 & 2246 & 1.78 & 0.69 & 4.74 \\
\hline Others & 8.26 & 109 & 2696 & 3.63 & 0.32 & 21.29 \\
\hline \multicolumn{7}{|l|}{ Haryana } \\
\hline All & & 1423 & 2441 & 1.22 & 0.54 & 4.07 \\
\hline SEA & 34.63 & 469 & 2613 & 1.86 & 0.46 & 8.39 \\
\hline SENA & 12.86 & 239 & 2314 & 2.16 & 0.62 & 7.76 \\
\hline RWS & 16.76 & 250 & 2520 & 3.80 & 0.50 & 12.04 \\
\hline CLA & 11.25 & 121 & 2218 & 3.24 & 0.65 & 9.79 \\
\hline CLNA & 17.05 & 251 & 2141 & 2.05 & 0.73 & 5.24 \\
\hline Others & 7.44 & 93 & 2760 & 5.99 & 0.32 & 25.23 \\
\hline
\end{tabular}

SEA, Self-employed in agriculture; SENA, Self-employed in nonagriculture; RWS, Regular wage/salary; CLA, Casual labour in agriculture; CLNA, Casual labour in non-agriculture. 


\section{RESEARCH ARTICLES}

of all the working groups. The households under SEA have the highest average protein intake ranging from $61.4 \mathrm{~g}$ (West Bengal) to $80 \mathrm{~g}$ (Punjab), while those under CLA and CLNA jointly hold the least average protein intake. The households under RWS have the highest average fat intake in West Bengal, Bihar and Uttar Pradesh, whereas those under SEA top the list in Punjab and Haryana, as milk and milk derivatives are listed as daily food items in these two states compared to the other IGP states. With higher income, the socio-economic status of rural households under SEA and RWS increases, resulting in more knowledge and awareness regarding health and healthy food items, whereas agricultural labours and other casual labourers consume inferior diet and nutrition in comparison to the other occupation types.

Table 4 shows the consumption pattern in rural households based on land holding size among the states of the

Table 3. Occupation-wise average protein, fat intake and $\% \mathrm{CV}$ in the IGP states

\begin{tabular}{|c|c|c|c|c|}
\hline Category & Protein (g) & $\% \mathrm{CV}$ & Fat (g) & $\% \mathrm{CV}$ \\
\hline \multicolumn{5}{|c|}{ West Bengal } \\
\hline All & 55.6 & 1.07 & 35.3 & 1.24 \\
\hline SEA & 61.4 & 3.49 & 37.6 & 2.31 \\
\hline SENA & 55.4 & 1.65 & 36.2 & 2.93 \\
\hline RWS & 58.8 & 2.88 & 43.5 & 3.31 \\
\hline CLA & 51.5 & 1.43 & 31.4 & 2.17 \\
\hline CLNA & 53.6 & 2.04 & 32.3 & 2.63 \\
\hline Others & 59.4 & 3.40 & 42.1 & 5.38 \\
\hline \multicolumn{5}{|l|}{ Bihar } \\
\hline All & 62.9 & 0.71 & 39.2 & 1.22 \\
\hline SEA & 66.1 & 1.35 & 41.9 & 2.16 \\
\hline SENA & 62.3 & 1.15 & 38.7 & 1.83 \\
\hline RWS & 67.4 & 1.84 & 46.6 & 3.26 \\
\hline CLA & 60.1 & 1.61 & 35.0 & 2.96 \\
\hline CLNA & 58.8 & 1.45 & 36.4 & 3.25 \\
\hline Others & 61.2 & 2.10 & 40.8 & 4.02 \\
\hline \multicolumn{5}{|c|}{ Uttar Pradesh } \\
\hline All & 62.6 & 0.53 & 42.6 & 1.01 \\
\hline SEA & 64.8 & 0.82 & 46.3 & 1.55 \\
\hline SENA & 60.6 & 1.21 & 39.1 & 2.28 \\
\hline RWS & 62.9 & 1.70 & 46.9 & 3.13 \\
\hline CLA & 59.5 & 1.79 & 35.9 & 2.69 \\
\hline CLNA & 60.2 & 0.94 & 38.7 & 1.99 \\
\hline Others & 64.0 & 3.70 & 43.4 & 6.68 \\
\hline \multicolumn{5}{|l|}{ Punjab } \\
\hline All & 70.0 & 0.96 & 70.3 & 1.34 \\
\hline SEA & 82.0 & 1.92 & 86.6 & 2.40 \\
\hline SENA & 65.6 & 1.47 & 65.5 & 2.68 \\
\hline RWS & 66.0 & 1.76 & 66.5 & 2.68 \\
\hline CLA & 66.3 & 2.61 & 57.3 & 3.55 \\
\hline CLNA & 62.0 & 1.89 & 59.7 & 2.19 \\
\hline Others & 70.5 & 3.49 & 83.0 & 4.61 \\
\hline \multicolumn{5}{|l|}{ Haryana } \\
\hline All & 72.8 & 1.24 & 68.6 & 2.08 \\
\hline SEA & 80.4 & 1.92 & 78.0 & 2.75 \\
\hline SENA & 68.0 & 2.28 & 60.8 & 3.56 \\
\hline RWS & 73.4 & 3.05 & 76.5 & 7.61 \\
\hline CLA & 64.5 & 3.62 & 55.2 & 4.67 \\
\hline CLNA & 62.0 & 2.07 & 51.8 & 3.00 \\
\hline Others & 82.2 & 6.20 & 81.8 & 7.37 \\
\hline
\end{tabular}

IGP region. The land-holding size-wise disparity in average calorie intake among the IGP states is lowest for Bihar (-1\% to $6 \%)$ and highest for Punjab (-4\% to $19 \%)$ compared to the overall average calorie intake of the respective states. The rural households other than marginal and small holders have the highest average calorie intake ranging from 2975 (Punjab) to $2379 \mathrm{kcal}$ (Bihar), except in West Bengal where small holders have the highest calorie intake. The marginal holders have the lowest average calorie intake that varies from 2163 (Uttar Pradesh) to $2373 \mathrm{kcal}$ (Punjab) in the IGP region. Further from Table 4, it can be observed that the proportion of food insecurity in the IGP states varies from 0.50 (Punjab) to 0.73 (West Bengal). The variation of food insecurity among the land-holder groups within a state is highest in Punjab $(-52 \%$ to $14 \%)$ and lowest in Uttar Pradesh $(-19 \%$ to $2 \%)$, compared to the proportion of food insecurity of the respective states.

Table 5 shows the land-holding size-wise average protein and fat intake in the IGP states along with their percentage CV. Again in this classification, irrespective of all the land-holding groups, Punjab and Haryana surpass the other states in the IGP region in average protein and fat intake. The land holders other than small and marginal groups have the highest average protein intake ranging from 66.2 (Bihar) to $87.9 \mathrm{~g}$ (Punjab), except in West Bengal where small holders have the highest and marginal

Table 4. Land category-wise distribution of households (\%), sample size, calorie intake, PFI and \%CV in the IGP states

\begin{tabular}{|c|c|c|c|c|c|c|}
\hline Category & $\begin{array}{l}\text { Distribu- } \\
\text { tion of } \\
\text { house- } \\
\text { holds (\%) }\end{array}$ & $\begin{array}{c}\text { Sam- } \\
\text { ple } \\
\text { size }\end{array}$ & $\begin{array}{c}\text { Calorie } \\
\text { (kcal) }\end{array}$ & $\% \mathrm{CV}$ & PFI & $\% \mathrm{CV}$ \\
\hline \multicolumn{7}{|l|}{ West Bengal } \\
\hline All & & 3566 & 2199 & 0.90 & 0.73 & 1.74 \\
\hline Marginal & 96.19 & 3318 & 2188 & 0.93 & 0.74 & 1.76 \\
\hline Small & 3.05 & 176 & 2484 & 2.54 & 0.55 & 12.50 \\
\hline Others & 0.64 & 72 & 2278 & 6.38 & 0.69 & 13.46 \\
\hline \multicolumn{7}{|l|}{ Bihar } \\
\hline All & & 3310 & 2242 & 0.73 & 0.68 & 2.15 \\
\hline Marginal & 86.42 & 2700 & 2219 & 0.82 & 0.70 & 2.17 \\
\hline Small & 8.14 & 297 & 2358 & 1.98 & 0.60 & 9.33 \\
\hline Others & 5.44 & 313 & 2379 & 2.53 & 0.48 & 12.89 \\
\hline \multicolumn{7}{|c|}{ Uttar Pradesh } \\
\hline All & & 5915 & 2200 & 0.51 & 0.72 & 1.34 \\
\hline Marginal & 83.90 & 4693 & 2163 & 0.55 & 0.74 & 1.36 \\
\hline Small & 10.33 & 647 & 2325 & 1.72 & 0.62 & 5.36 \\
\hline Others & 5.77 & 575 & 2413 & 1.84 & 0.58 & 7.26 \\
\hline \multicolumn{7}{|l|}{ Punjab } \\
\hline All & & 1552 & 2483 & 0.91 & 0.50 & 3.67 \\
\hline Marginal & 81.07 & 1189 & 2373 & 0.93 & 0.57 & 3.63 \\
\hline Small & 7.28 & 99 & 2655 & 2.65 & 0.34 & 19.87 \\
\hline Others & 11.65 & 264 & 2975 & 2.63 & 0.24 & 17.16 \\
\hline \multicolumn{7}{|l|}{ Haryana } \\
\hline All & & 1423 & 2441 & 1.22 & 0.55 & 4.07 \\
\hline Marginal & 73.69 & 1030 & 2351 & 1.58 & 0.60 & 4.34 \\
\hline Small & 12.91 & 153 & 2576 & 2.67 & 0.49 & 12.07 \\
\hline Others & 13.40 & 240 & 2698 & 2.44 & 0.37 & 14.30 \\
\hline
\end{tabular}


land holders have the least average protein intake. Punjab and Haryana have the highest average fat intake, irrespective of the land-holding groups. Here also, groups other than small and marginal land holders, have the highest average fat intake that varies from 44.9 (Bihar) to 93.9 (Punjab). It can be observed that irrespective of the states, the marginal land holders have the least average calorie, protein and fat intake compared to the other landholding groups, though they share the highest percentage of the total population. This may be because of their low income which prevents them from consuming healthy and nutritious food when compared to households which possess greater land-holding size.

The analysis also indicates that regional factors like casteism determine the level of food insecurity across various groups. Tables 6 and 7 show that food consumption pattern in rural India varies according to socioeconomic groups. The socio-economic group-wise disparity in average calorie intake among the IGP states is lowest for West Bengal $(-1 \%$ to $4 \%)$ and highest for Punjab $(-7 \%$ to $15 \%$ ), compared to the overall average calorie intake of the respective states. The food insecurity within a given state is lowest in Punjab and varies from 0.20 to 0.56 , while it is highest in West Bengal and ranges from 0.67 to 0.78 . In the case average protein and fat intake, Punjab and Haryana top the list. On an average, socio-economic groups other than ST, SC and OBC have the highest average protein and fat intake, while SC consumes the least. Here casteism is interlinked with wealth, earnings

Table 5. Land category-wise average protein, fat intake and percentage $\mathrm{CV}$ in the IGP states

\begin{tabular}{lcccc}
\hline Category & Protein $(\mathrm{g})$ & $\% \mathrm{CV}$ & Fat $(\mathrm{g})$ & $\% \mathrm{CV}$ \\
\hline West Bengal & & & & \\
All & 55.6 & 1.07 & 35.3 & 1.24 \\
Marginal & 55.2 & 1.11 & 34.8 & 1.28 \\
Small & 65.1 & 2.92 & 45.3 & 4.23 \\
Others & 58.7 & 7.51 & 44.8 & 6.02 \\
Bihar & & & & \\
All & 62.9 & 0.71 & 39.2 & 1.22 \\
Marginal & 62.3 & 0.79 & 38.2 & 1.35 \\
Small & 66.4 & 2.13 & 44.1 & 3.49 \\
Others & 66.2 & 2.21 & 44.9 & 4.39 \\
Uttar Pradesh & & & & \\
All & 62.6 & 0.53 & 42.6 & 1.01 \\
Marginal & 61.3 & 0.57 & 40.2 & 1.07 \\
Small & 67.1 & 1.67 & 51.5 & 3.35 \\
Others & 69.9 & 2.03 & 56.1 & 2.94 \\
Punjab & & & & \\
All & 70.0 & 0.96 & 70.3 & 1.34 \\
Marginal & 65.9 & 0.92 & 64.7 & 1.41 \\
Small & 77.4 & 3.18 & 81.4 & 3.98 \\
Others & 87.9 & 2.70 & 93.9 & 3.05 \\
Haryana & & & & \\
All & 72.8 & 1.24 & 68.6 & 2.08 \\
Marginal & 69.1 & 1.52 & 63.6 & 2.75 \\
Small & 80.1 & 2.99 & 76.2 & 4.79 \\
Others & 82.3 & 2.80 & 83.0 & 4.13 \\
\hline & & & & \\
\hline
\end{tabular}

and opportunities, and the rural households being at the bottom of the social ladder are at a high risk of premature death, poor health and lack of treatment. Thus a healthy diet with higher calorie, protein and fat intake is followed in the households belonging to higher caste groups, whereas the consumption pattern is poor among SC and ST households, except in Punjab.

\section{Conclusion}

The present analysis demonstrates the average calorie, protein and fat intake among rural households in the IGP states on the basis of their land-holding capacity, occupation and socio-economic status, as well as dietary diversity and disparity in food security. The inequality in nutritional consumption and food security is higher in the rural households of the IGP states where agriculture is not a prime source of income. Being recognized as major agricultural states of India, Punjab and Haryana possess significantly different dietary patterns (i.e. the population consumes more calorie, protein and fat) than the other three states of the IGP region, and the proportion food

Table 6. Social group-wise distribution of households (\%), sample size, calorie intake, PFI and percentage $\mathrm{CV}$ in the IGP states

\begin{tabular}{|c|c|c|c|c|c|c|}
\hline Category & $\begin{array}{c}\text { Distribution } \\
\text { of house- } \\
\text { holds }(\%)\end{array}$ & $\begin{array}{c}\text { Sample } \\
\text { size }\end{array}$ & $\begin{array}{c}\text { Calorie } \\
\text { (kcal) }\end{array}$ & $\% \mathrm{CV}$ & PFI & $\% \mathrm{CV}$ \\
\hline \multicolumn{7}{|c|}{ West Bengal } \\
\hline All & & 3566 & 2199 & 0.90 & 0.73 & 1.74 \\
\hline ST & 7.76 & 200 & 2164 & 2.45 & 0.73 & 6.45 \\
\hline $\mathrm{SC}$ & 32.26 & 1064 & 2165 & 1.09 & 0.78 & 2.80 \\
\hline $\mathrm{OBC}$ & 7.62 & 375 & 2297 & 1.76 & 0.67 & 6.26 \\
\hline Others & 52.34 & 1927 & 2211 & 1.50 & 0.72 & 2.53 \\
\hline \multicolumn{7}{|l|}{ Bihar } \\
\hline All & & 3310 & 2242 & 0.73 & 0.68 & 2.15 \\
\hline ST & 1.76 & 45 & 2296 & 4.35 & 0.59 & 22.89 \\
\hline $\mathrm{SC}$ & 19.56 & 552 & 2167 & 2.06 & 0.77 & 4.00 \\
\hline $\mathrm{OBC}$ & 60.16 & 1980 & 2239 & 0.88 & 0.68 & 2.79 \\
\hline Others & 18.52 & 733 & 2324 & 1.66 & 0.61 & 5.53 \\
\hline \multicolumn{7}{|c|}{ Uttar Pradesh } \\
\hline All & & 5915 & 2200 & 0.51 & 0.72 & 1.34 \\
\hline ST & 1.22 & 67 & 2143 & 5.58 & 0.68 & 13.02 \\
\hline $\mathrm{SC}$ & 27.20 & 1500 & 2157 & 1.01 & 0.73 & 2.60 \\
\hline $\mathrm{OBC}$ & 54.81 & 3168 & 2188 & 0.67 & 0.73 & 1.76 \\
\hline Others & 16.76 & 1180 & 2306 & 1.30 & 0.65 & 3.53 \\
\hline \multicolumn{7}{|l|}{ Punjab } \\
\hline All & & 1552 & 2483 & 0.91 & 0.50 & 3.67 \\
\hline ST & 0.18 & 3 & 2870 & 16.2 & 0.20 & 100.63 \\
\hline $\mathrm{SC}$ & 48.68 & 692 & 2289 & 1.12 & 0.62 & 4.25 \\
\hline $\mathrm{OBC}$ & 12.54 & 179 & 2410 & 2.57 & 0.56 & 9.30 \\
\hline Others & 38.59 & 678 & 2747 & 1.37 & 0.34 & 7.71 \\
\hline \multicolumn{7}{|l|}{ Haryana } \\
\hline All & & 1423 & 2441 & 1.22 & 0.55 & 4.07 \\
\hline ST & 1.50 & 21 & 2221 & 5.73 & 0.80 & 11.56 \\
\hline $\mathrm{SC}$ & 27.22 & 410 & 2331 & 2.49 & 0.65 & 5.80 \\
\hline $\mathrm{OBC}$ & 26.97 & 376 & 2259 & 1.76 & 0.64 & 5.69 \\
\hline Others & 44.31 & 616 & 2618 & 1.78 & 0.43 & 7.98 \\
\hline
\end{tabular}

ST, Scheduled caste; ST, Schedule tribe; OBC, Other backward class. 
Table 7. Social group-wise average protein, fat intake and $\% \mathrm{CV}$ in the IGP states

\begin{tabular}{|c|c|c|c|c|}
\hline Category & Protein (g) & $\% \mathrm{CV}$ & Fat (g) & $\% \mathrm{CV}$ \\
\hline \multicolumn{5}{|c|}{ West Bengal } \\
\hline All & 55.6 & 1.07 & 35.3 & 1.24 \\
\hline ST & 61.4 & 3.49 & 37.6 & 2.31 \\
\hline $\mathrm{SC}$ & 55.4 & 1.65 & 36.2 & 2.93 \\
\hline $\mathrm{OBC}$ & 58.8 & 2.88 & 43.5 & 3.31 \\
\hline Others & 59.4 & 3.40 & 42.1 & 5.38 \\
\hline \multicolumn{5}{|l|}{ Bihar } \\
\hline All & 62.9 & 0.71 & 39.2 & 1.22 \\
\hline ST & 63.1 & 3.90 & 34.1 & 11.33 \\
\hline $\mathrm{SC}$ & 60.3 & 1.77 & 36.2 & 3.20 \\
\hline $\mathrm{OBC}$ & 62.9 & 0.89 & 39.2 & 1.54 \\
\hline Others & 65.6 & 1.68 & 42.8 & 2.48 \\
\hline \multicolumn{5}{|c|}{ Uttar Pradesh } \\
\hline All & 62.6 & 0.53 & 42.6 & 1.01 \\
\hline ST & 61.6 & 5.97 & 43.0 & 10.37 \\
\hline $\mathrm{SC}$ & 60.9 & 1.02 & 37.5 & 2.07 \\
\hline $\mathrm{OBC}$ & 62.4 & 0.70 & 42.4 & 1.24 \\
\hline Others & 65.9 & 1.26 & 51.2 & 2.51 \\
\hline \multicolumn{5}{|l|}{ Punjab } \\
\hline All & 70.0 & 0.96 & 70.3 & 1.34 \\
\hline ST & 81.6 & 18.08 & 81.6 & 18.08 \\
\hline $\mathrm{SC}$ & 63.7 & 1.17 & 63.7 & 1.17 \\
\hline $\mathrm{OBC}$ & 67.2 & 2.57 & 67.2 & 2.57 \\
\hline Others & 78.7 & 1.45 & 78.7 & 1.45 \\
\hline \multicolumn{5}{|l|}{ Haryana } \\
\hline All & 72.8 & 1.24 & 68.6 & 2.08 \\
\hline ST & 61.8 & 5.14 & 50.7 & 8.28 \\
\hline $\mathrm{SC}$ & 66.9 & 2.40 & 59.4 & 4.76 \\
\hline $\mathrm{OBC}$ & 67.5 & 2.00 & 61.3 & 2.77 \\
\hline Others & 79.7 & 1.76 & 78.5 & 2.90 \\
\hline
\end{tabular}

insecurity is also low, irrespective of the indicators which include land-holding capacity, occupation and socioeconomic status. The analysis shows how disparity in nutrition intake arises, which in turn accounts for increase in food insecurity level of the IGP states. Land holders other than marginal and small farmers, show the highest level of nutritional consumption in Punjab and Haryana, whereas rest of the states have similar consumption pattern irrespective of the land-holding size. Self-employed agricultural labourers are more in these two states which makes the rural households, categorized under SEA occupational group, more nutritionally secure. In the case of West Bengal, Uttar Pradesh and Bihar, the number of self-employed agricultural labourers is less as these states are mainly based on marginal and small land-holding groups. Rural households in these three states mainly consist of daily wage labourers, which results in poor dietary outcome.

The present study also indicates that a large proportion of our population is malnourished and anaemic. There is an urgent need to build some accord on the standards for minimum necessary calorie intake as these factors are important with respect to the seriousness of craving and under-nourishment in our nation. Hunger and under- nourishment lead to severe problems. Children and youth experience the ill-effects of various nutritional deficiencies which unfavourably impact their health and wellbeing, as adequate food and nutrition is the foundation for a healthy and productive life and the basic prerequisite for all other interventions.

GoI has undertaken various measures to ensure food security through increased production of food grains, preventing food adulteration, monitoring and strengthening nutrition programmes, popularizing low-cost nutritious food and improving dietary patterns by encouraging production and increasing per capita availability of nutritionally rich food. Government policies like Integrated Child Development Services, Food Security Bill, National Food Security Act, National De-worming Day, National Iron+ Initiative, National Health Mission, etc. have been introduced, and the Food Safety and Standards Authority of India has also set nutritional benchmarks to guarantee that fortified food items include the desirable levels of micronutrients. The State Government agencies need to implement a comprehensive and coordinated multisectorial approach by considering various local-level challenges. In particular, we need to focus upon building several effective health and nutrition profiles, carrying out interventions based on the identified needs, and making appropriate nutrition available and affordable to our population. We have made our devices brilliant and smart, without which we can endure, however it's high time now that we make our diet and nutrition regime additionally wise and smart.

1. Cagliarini, A. and Rush, A., Economic development and agriculture in India. Reserve Bank of Australia Bulletin, June quarter, 2011.

2. Chand, R. and Jumrani, J., Food security and undernourishment in India: assessment of alternative norms and the income effect. Indian J. Agric. Econ., 2013, 68(1), 39-53.

3. World Bank Report, Conflict, security, and development, Washington DC, USA, 2011.

4. Basu, D. and Basole, A., The calorie consumption puzzle in India: an empirical investigation. Economics Department Working Paper Series, Paper No. 147, 2012; http://scholarworks.umass.edu/econ_ workingpaper/147.

5. Deaton, A. and Dreze, J., Nutrition in India: facts and interpretations. Econ. Polit. Wkly, 2009, 44(7), 42-65.

6. Meenakshi, J. V. and Vishwanathan, B., Calorie deprivation in rural India, 1983-1999/2000. Econ. Polit. Wkly, 2003, 38(4), 369-375.

7. Patnaik, U., A critical look at some propositions on consumption and poverty. Econ. Polit. Wkly, 2010, 45(6), 74-80.

8. World Food Summit, Declaration on world food security, Food and Agriculture Organization, Rome, Italy, 1996.

9. MoSPI, Level and pattern of consumer expenditure, 2011-12. Ministry of Statistics and Programme Implementation, Government of India, 2014.

10. Särndal, C. E., Swensson, B. and Wretman, J. H., Model Assisted Survey Sampling, Springer-Verlag, New York, USA, 1992.

Received 31 October 2019; accepted 7 September 2020

doi: $10.18520 / \mathrm{cs} / \mathrm{v} 119 / \mathrm{i} 11 / 1783-1788$ 